\title{
Arab dialects that formed the classical Arabic, in which the Holy Qur'an was revealed
}

\author{
Salahuddin Mohd. Shamsuddin \\ Islamic University Sultan Sharif Ali - Brunei Darussalam \\ Arman Bin H. Asmad \\ Assistant Rector, \\ Islamic University Sultan Sharif Ali - Brunei Darussalam \\ Siti Sara Binti Hj. Ahmad \\ Dean: Faculty of Arabic Language, \\ Islamic University Sultan Sharif Ali - Brunei Darussalam
}

\begin{abstract}
Arabic is one of the Semitic languages: Syriac, Hebrew and Arabic. Syriac was the language of peoples whose effects and history had disappeared. Hebrew was the language of Torah and Scriptures had been extinct by the extinction of primitive cultures and ancient messages. Arabic was and is still alive with its other sisters living in the world. It is the language of an immortal divine message. God has adapted it to be the language of His Speech (Revelation) or (Qur'an), as it is stated in the verse: "We have brought down the Qur'an and we will save it". It is necessary to sanctify the eternal and miraculous language of God. As well as, it is the language of Muhammad The prophet who brought a religion unites the hearts and souls by the love and faith, to spread peace and security in every part of the world, and presented to all of the human societies a comprehensive and universal message was the message of removal for all of the ancient religious messages. The language of this last universal message is Arabic, and its universality lies in its universal message to all people. This is the teaching of Muhammad The prophet: "Arabic is not by the father or the mother, whoever speaks Arabic is an Arab". The classical Arabic is the language of all Arabs and Muslims who believe in its universal message. We are talking about those dialects that made up the Arabic language, as the language of the holy Qur'an.
\end{abstract}

Keywords: 1. Arab Tribes, 2. Arab Dialects, 3. Dialect of Himyar, 4. Dialect of Quraish. 5. Standard Arabic, 6. Language of the Qur'an.

\section{INTRODUCTION: ARABIC LANGUAGE}

No doubt that each language has its suitable place. If we try to quote here what is written about it before, will not be enough. Therefore, it is better to choose a page has been written by Muștafā Șādiq al-Rafi'ī in his book: "History of Arabic Literature and Standard Arabic", It is imperative that if we want to record words in the definition of classical Arabic or to express what was written about it was difficult to consider it better than what was written, but can be considered as little of the lot stated in its statement, I think it is better to quote a page written by Mustafa Sadiq Al-Rafi'i in "The History of the Literature of Arabs" and their classical Arabic, he says: "It is decided by the wise men, that the language is rich because of its vocabularies. The wide condition of their disposing is a clear evidence for the civilization of its people, and their capacity under the shadow of their society. There is nothing to mention for the Arabs except that they had a literal civilization characterized by the nature; as they had noting in the science of metals and places of industries. There was not in their hands the tools of Nations and 
social facilities except a few belongings do not reach in its entirety to be a brief explanation of the term (the Arabs) in the dictionary of Nations. The wisdom that made the Old civic arts in the hands of Chinese, and civic sciences in the minds of Greeks, it is summarized the civilization of languages for the tongues of Arabs.

If we think about the meaning of civilization, including its benefit for us, we have seen it in every society in two forms: the first form is the image of the individual in his core, and the second is the apparent image of the group. The urbanization will not be true only if it is based on the mental qualities found in per capita including his preparation for the virtues that are the material of the changing in the mental growth and creation of a new origination entails the emergence of history in total. There is no doubt that the apparent atmosphere of the group is the mirror of inner changes in the individuals. The society in its meaning is such as the combined effects of the minds and the history of psychological changes.

If we consider that in the Arabs we have not seen it in them as the fact nor as the appearance, but only in the language, because it is not enough for Arab to be on an innate morality protected by the borders of desert, and maintained by the walls of natural liberty, so that it can be said that there is a developing soul in Arabs for the literature; because this literature did not occur the mental changes in them that can be appeared in the image of their group, but in the last reign of their ignorant age when they entered in Islam, but if we consider their language we see the fact of urbanization represented, with all of its necessary conditions; it was the sea of life, which focused all the elements spewed out this mental power in their own perfect language.

The wisdom gave their nature this linguistic system, and made them to do the best for the process of its perfection, so that they do not face any obstacle to change their faces from the civil system. They went on that language beyond the social grades step by step, and at the end they became united in the unity of a nation in the world, then they changed completely, as a new young force faced by the old countries with a shock that demolished the history and then wrote a new history. If there was not this language the Arabs could not be organized because their generations to generations had spent before in the urbanization of their language, but they did not prove any talent in themselves, they did not consider the nature social system, which is a way to save the life, to complete the system of life, as it is concerned by the social civilization. The language leaded them to the social ethics by the poetry, to the policy guidance by the rhetorical speech, and to the religious guidance by the Holy Qur'an.

The faces of urbanization that suit the natures of the civilian purposes are those grammatical signs that specify the meanings and purposes by the most convenient signal that are the features of mental Highness specifically. (1)

\section{Search Questions:}

A. What are the dialects of the main Arab tribes that formed the classical Arabic?

B. What is the concept of this saying: "The Qur'an is revealed on seven characters, so you all can read it with the easier one of them"? Does it mean the seven number or it is a kind of permission?

C. What are the seven readings of the Holy Qur'an?

D. What are the reliable dialects in the concept of the seven readings?

\section{ARAB TRIBES}

Arabs are divided into two major parts or two main classes: The lost Arabs who lived and died, and the Arabs who were counted as the original Arabs. 
A. The lost Arabs were those Arabs whose tribes perished and their effects disappeared and their news broke, they were nine: 'A $\bar{\alpha} d$, Thamūd, Țasm Jadīs, Umaim, 'Abīl, Jurhum, Jōsim and 'Amlīq, but the most famous of them are the first four tribes who are called as the original Arabs. The second class of them is the Arabized or alienated Arabs, who are the sons of Isma'il b. Ibrahim. Some of the historians divided the Arabs into two classes: The first are 'A $\bar{\alpha} \mathrm{d}$, Thamūd, Țasm and Jadīs, and they are called Qaḥtān Arabs, and the second are Adnan who are not original Arabs, but they have become multicultural Arabs.

B. As for the original Arabs, so called for their roots in Arabic, and considered by the historians the oldest inhabitants of the Arabian Peninsula, as they promise Semitic descendants of Arm b. Sam, but the Giants were descendants of Oud b. Sōm who was Iram's brother. It is said that the people of 'A $\bar{\alpha} \mathrm{d}$ and most of the ancient giant Arabs were from the breed of Hōm, who have been mentioned in the Qur'an for the example of the pride and highness, which led them to the destruction.

\section{DIALECTS OF ARAB TRIBES IN THE PRE-ISLAMIC ERA}

The historians swear the ignorance period into two: the first ignorance period and the second ignorance period. We do not know anything about the first one, but through what is mentioned about it in the Qur'an. The second ignorance period is one hundred and fifty years or two hundred years mostly before Islam. The first Arab poet is Imra' -ul- Qais b. Hujr or Al-Muhalhal b. Rabi'a, as it is mentioned by Al-Jāhị in his book: (The animal). (2) Scientists of the languages do not differ in the presence of different Arab dialects in that period of time, as we see in the view of Abu 'Amr b. al-'Alā: "The tongue of Himyar and the ends of Yemen is not our language, and their culture is also not our Arabian culture", but some orientalists deny the existence of a common language before Islam, as we see that the orientalist David Samuel Margoliouth aimed at the questioning about the pre-Islamic poetry and at the same time about the Islam, saying: All the poems of the pre Islamic era that reached us was in the language of the Qur'an, they do not represent the multiple accents of Arab tribes in the Pre Islamic Era, then do not represents the difference between the language of Al-'Adnānyyīn in the north and Al-Himyaryyīn in the south. (3)

The difference between the accents of the southern (al-Yemenī) and northern (al-'Adnānī) is a fact, as we see Ibn Jinnì accepts this fact saying:

"There is no doubt that the language of Himyar and other languages like that were far away from the language of Bnī Nazār"... "When the scholars wanted to narrate the language found the tribes varying in eloquence had ruled out the language of Himyar, because it was almost alone as being a different language to Arabic language of Mudar, as they had contacted to Abyssinia, Jews and Persians. So their language was affected by the other languages. (4)

Here we say: The northern tribes began to attack on the south since the middle of the fourth century AD, after the weakness of Himyarite state, and the tribes settled and published their language in the south of the island, as well as, a large number of Arabs in the south migrated to the north, and adopted the language of northern peoples. We know from the inscriptions found in the Arabian Peninsula that the Arabic writing has evolved in the northern Hijāz, and the inception was from the Nabatean writing, as the language used for the writing of these inscriptions is Arabic in its different phases.

Shawqī Daif Says: "We have in our hands some of the pre-Islamic poetry indicates conclusively that all of the Arab tribes in the north decided to develop a standard literary dialect, the poets of different tribes were composing their poetry in this tone. When the poet was composing his poetry was rising from the local tone of his tribe to this common literary tone. Then other 
properties characterized by each local tone of each tribe disappeared, even those characteristics were not shown in the poetries of their poets, but some time in a very little form, (5) there are accounts indicate the presence of the standard Arabic language in the pre Islamic era, namely:

* 'Abu Nașr al-Fārābii says: Quraish was the finest tribe among all of the Arab tribes in the selecting the most eloquent and the easiest word on the tongue in the pronunciation, the best in the hearing and the most excellent in the explanation of what was in the soul.

* 'Ahmad b. Fāris says quoting from Ismā'īl b. 'Abi 'Ubaid Allah: "All of the scholars of Arabic language, the narrators of poetry, Arab linguists and the scientists of the wars and trade centers had accepted that Quraish was the most eloquent and the finest tribe among the all Arabs in their tongues and languages, so that Allah selected them among all of the Arabs and chose Muhammad one of them to be the Prophet of Mercy, making Quraish the protector and sponsor of Kā'ba and neighbor of His house. Therefore, the delegations of Arab pilgrims and others were coming to Mecca for Hajj, then to Quraish arbitrating in their affairs. If the delegations came to them, they were with their fluency, good language and good tongue choosing the best words of Arabic language and poetry. So they became the most eloquent among the all of Arab tribes. Therefore, you do not find in their words the verbal errors like the errors of Tamìm, Qais, 'Asad and Rabi'a". (6)

* According to Ibn Khaldūn: "The language of Quraish was the most eloquent and explicit language among all of Arabic tongues, because it was far from the countries of NonArabs in all directions, this distance from Persians saved them from linguistic errors and being influenced by Persian styles, so in the linguistic issues the witnesses for the right and wrong were taken from the language of Quraish to the people of industry of Arab language. (7)

* Here, Shawqī Daif said: "There were some religious, economic and political factors prepared for the tone of Mecca to lead the other tribal dialects in the Pre-Islamic Era. The Arab tribes had been seeing by their own eyes that the neighboring countries: Persia, Rom and Ethiopia were attacking on their lands, as they also had been seeing that the Judaism and Christianity these two religions were attacking on their pagan religion, so their hearts gathered around Mecca. Thus, there was an opportunity for alQuraishiyya dialect to prepare itself to control the different tribal dialects in the preIslamic era and become itself the literary language for their prayers, their thoughts and feelings. This is further supported by the narrators sayings that Arabs "were presenting their poems to Quraish, which was accepted by Quraish was acceptable to all of the Arabs and which was rejected by Quraish was rejected by the all." (8)

There was a difference between the Yemeni and 'Adnāni dialects before the collapse of Ma'rib dam, which separated between Qahțānian and Himyarian. Then they migrated to all parts of the Arabian Peninsula and mixed up with their 'Adnānian brothers after their resettlement, even the tribe of 'Azd including Jurhum, 'Aws and Khazraj stabilized in the city (Medina), while Kindah from Yemen, which was the place of the tribe of Imr'-ul-Qays (the poet) settled in al'Arud in the north and Khuzā'ah in Mecca, as being in the vicinity of Quraish. Some tribes like Huzayl and Kināna were settled in the land of Yemen. Many other tribes and their branches gathered in Iraq and Syria to the north and south and played an important role in the movement of Islamic conquest. (9)

After all of these migrations, stability of Yemenis and their mixing with 'Adnānis through intermarriage, neighborliness, governance, accommodation and cohabitation, this language was converged and the differences between Arabic dialects were very slim. 
As it is stated in the words of Al-Jāhiz in his book "The statement and interpretation": "The people of Mecca said to Muhammad b. Manādir a poet of Tamīm addressing the people of Basra that you don't have an eloquent language, but we the people of Mecca have an eloquent language". Ibn Manādir said that our word is the most approval to the Qur'an, you put the Qur'an after this as you like... Then he mentioned some examples of the disagreement among the Arabic dialects, but he does not deny the existence of a unified Arab common language. (Margoliouth and his position to the Arabic poetry by Muhammad Muṣțafā Haddāra) (10) Therefore, the danger presented by Margoliouth and who followed him like Țāhā Husayn no longer remained.

We want to say that the classical language of Quraish prevailed in the Pre-Islamic Era, and poets since the beginning of this era were composing their poetries in this language. The tone of Quraish prevailed because of the religious, economic and political factors. The poets were composing their poetries in this language leaving their local tone as we mentioned earlier in this regard or somehow we see Arab poets make in this age according to the differences of their countries and regions. The pre-Islamic poetry does not represent the language of Himyar tribes in the south of the Arabian Peninsula. Yes, this is normal, because they were not using the literary language of poetry, as we see in the words of 'Abu 'Amr b. al-'Ala': "The language of Himyar and the people in the end of the Yemen was not like our Arabic language and their Arab culture also was not like our Arab culture." The classical Arabic had taken - as it is written by Shawqī Daif - stormed the doors on this language in the same Pre-Islamic Era, so we can say that Urbanization of the southern peoples began since the early eras.

Shawqi Daif adds that there are some images of the styles and compositions in the Pre-Islamic Poetry, that are different to the natural grammatical image, which indicates their oldness, and they are not made by the Abbasids and also there is the image of the moral deviation, which cannot be found except in the nature of the pagan as we see in the poem of Imra'-ul-Qais, which is one of the seven Pendants. (11)

Then we see Lyle back to this topic in his introduction: "Divan of 'Obaid b. al-Abraș", saying: It is confirmed that the narration of the poetry continued active since the pre Islamic Era until it was written finally in the Abbasid era. It is due to the pendants, for example, we find each of them in a clear and unique personality. It proves that it belongs to its owner. Lyle returned to what he said first in his "introduction" that the simulation of the poetry in the first century H. required the existence of the pre-Islamic poetry, which shared with it in the same tradition, and also there were some exotic words that were not used in the era of these narrators who wrote it. It is a demonstrating conclusive indication that it is true in its essence.

\section{ADNANITES AND CLASSICAL ARABIC}

As for the Adnanites, the Arabized Arabs were told that Ismael spoke Hebrew. When Arabs of the Qahtāniyah tribe came and settled down in Mecca, they lived with Ismael who married the girl was one of them. Then he and his Arab sons learned Arabic and called the Arabized Arabs, the Arab population of Bedouins and the urban dwellers spread in the middle of the Arabian Peninsula and Hijāz to Shōm.

It is known that the Arabic language remained centuries before the history of pre-Islamic era. It was developed and composed, and had taken all the reasons that complete its characteristics, in which the factors of growth varied from substitution, derivation, carving and Arabization until emerged in the full matured form to the history. 
The Arabs wanted to form a literary tone can be a tool for expressing the Arab conscience, and can be used by the speakers, literary persons and wise men. This classical literary language had spread over the Arabian Peninsula, as the Arabs and the tribes had accepted it. Meanwhile, their tribal ton remained to be used in non-literary expression, such as the conversation and daily life, depending on the environment in which they were living, following the different methods of development and improvisation. (12)

The classical Arabic language emerged and flourished in the period, in which its artistic characteristics were completed. Imr'-ul-Qais from Yemen and Labīd b. Rabi'a al-Mudari al'Adnōnī both were using the same Arabic language in their dialogue and poetry. As the result, Arab poets were divided into the regional poets and public poets. The creation of a literary language had many factors, as according to their suffering it was essential and necessary to them to unify a language brings them all together, and can be a vessel for their literature. This literary language was a fruit of the rapprochement among the languages of tribes and clans, in which the Holy Qur'an was revealed. (13)

Some Arab orientalists and researchers ignored this historical background that the northern tribes had begun to attack on the south since the middle of the fourth century AD, after the weakness of Himyar state, when the tribes of Himyar had settled and spread their language in the south of the island, as well as, a large number of southern Arabs had migrated to the north, and adopted the language of the northerners. It is known by the inscriptions found in the Arabian Peninsula that the Arabic calligraphy had evolved and developed in the north of Hijōz, and it was developed by the Nabataea calligraphy, and those inscriptions were written by the language was Arabic language in its different stages.

As for the origin of the classical Arabic language, the history tellers are known for their knowledge do not trust the pre-Islamic poetry, which is one hundred and fifty years before Islam, otherwise it is a common myth and fabricated news. Indeed, no one said that there was a unified Arabic language except within two centuries before Islam.

However, the assumption raised by some researchers that classical Arabic did not exist anywhere in the island before Islam, was unreasonable. It was not understood that the Qur'an revealed in a language to those people who did not know that language, as that language was not their own language or language of one of their tribes. As well as, it was not the strange that the Qur'an was revealed by God to His Prophet in his own language and the language of his people. Despite the fact that there were other views of the orientalists in that dialect used by the poets as the language of their poetry. However, there were some other valid narrations had indicated about the existence of the classical Arabic in the pre-Islamic Era, including the narration of Ahmad b. Fōris depending on the authority of Isma'il b. Abu'Ubaid Allah who said: "The scholars of Arab speech, the narrators of their poems, and the scholars of their language, their days and their homelands had agreed that Quraish had the best tongue of the Arabs, because Allah (the Almighty) chose them from all of the Arabs and chose one of them prophet of the mercy Muhammad, Allah made them neighbors of His house to keep it, so the Arabs were prosecuted to Quraish in their affairs, and Quraish was with its façade, its good language and good tongues if delegations came from the Arabs to Quraish choose the best language for their words and poems. Therefore, Quraish was the most eloquent among the Arabs. (14)

There were religious and economic reasons that prepared the dialect of Adnanites to prevail among the tribal dialects in the pre-Islamic era, where the political reasons were intertwined. The Arab tribes saw by their eyes the attack by the neighboring people: Persians, Romans and Abyssinians on their sides. They also saw the attack by the two religions: Judaism and 
Christianity on their pagan religion. Therefore, they thought about Mecca and its importance to their unity. In this way, the dialect of Quraish was able to prevail among the other different tribal dialects in the pre-Islamic era and became a literary language, in which they formulated their prayer, ideas and feelings. This is supported by the narrators who narrated that the Arabs "were presenting their poems to Quraish, if they accepted them were acceptable and if they refused were unacceptable to all tribes". (15) As well as, al-Baghdadi mentioned in his book: "Treasury of the literature: "In the ignorance era, if some of Arabs prepared a poetry and was far away from the Arab land, was not read by anyone, until he came to Mecca during the pilgrimage season, and presented it to the clubs of Quraish, if they liked it was narrated...".

\section{QAḤTĀNIYANS AND QAḤTĀNI DIALECT}

The land of Yemen was the home of the people of Qạ̣tān. It was attributed to Qaḥtān b. 'Aabir b. Shalih who was the first king of the land of Yemen. He wore the crown and was called the descendants of Yemenite's Qaḥtān or Qahtāniyans, while the offspring of Ishmael b. Ibrahim was called "Adnanites" or "Nizaris". These words became synonymous with the Arabs in the South and Arabs in the North. Qaḥtān - the grandfather of the South - left his son "Ya'rub" who was the first took Arabic as his tongue and was called by the poets: "Lord of the eloquence".

Hence, Qaḥtānians were called the Arabized or Arabicized Aran, but there is a saying that the attribution of Arabic language to "Aabir" or "Ya'rub" was based on the verbal similarity only, because these names in the Torah were not as we see in Arabic.

The people in the south lived a stable life, while the people in the north were mostly living a life of Bedouin and migration. The language of Yemenis was contrary to the language of the Adnanites according to their situations and atmospheres of its use. As the tongue of the people in the South includes various dialects, the most important ones are: Ma'iniyya, Saba'iya, Qatbaniya, Ausaniya and Hadramiyya that are close to the Semitic Abyssinian dialects.

People of Sabaean state were the Qahtānians originally who were called "Arabized Arabs". The scholars refer their origin to Abyssinia, and according to their investigation, the emergence of their state was between the eighth century and the year $115 \mathrm{BC}$. They had adopted the language of Mainians. Perhaps this was the cause that historians said that they took the Arabic language from the Arabized Arabs: Obviously, this Arabic language cannot be the language of Muḍar.

However, the origin of this Arabic language must be from Abyssinians, Himyarians, and the other Semitic languages, because the Arabs were the traveler people, they were mixed with many nations, so the effect of this mixing must have an impact on the composition of their language, which is a general method in all languages. Thus, Arabic was in its first rise until the tribes were struck in the desert after the stream of 'Uram, and then the Arabic way became independent, and its people went out to take care of its derivation. Therefore, it is not possible to assert that the Adnōnian Arabic has a particular origin unless it is possible to decide that they have a stable state and a certain civilization in the history, which is required to prove the originality of language, and this is not said by anyone, because it has no place in history.

\section{NEIGHBORING TRIBES OF QURAISH}

When linguists in the second century came to the tribes in Najd, to collect their material, they were searching for the springs that were still pure. Their work had no question about the language of Mecca during the pre-Islamic era and period of descent of the holy Qur'an. They looked for their target in the neighboring tribes of Quraish, such as Kanana, Huzail and some tribes of Qais. Surely, the differences between the dialect of Mecca and the dialect of these tribes were negligible in pre-Islamic era, and these differences widened as we moved to the 
south, east, or north, but we should not exaggerate in their perception. Since the early days of the pre-Islamic era, the poets have been able to broadcast the dialect of Mecca in their tribes when they were composing their poems.

It means that the Quraish dialect had not started to spread among the Arabs in Islam, but it had started to spread since the pre-Islamic era, and even since its earliest time, the oldest texts are like the most recent, organized in the Quraish dialect, which they adopted as a common literary language for them.

Perhaps one of the reasons, which also misled the orientalists and pushed them out of the correct argument was that they found the linguists, when they began to collect their linguistic material went to the Najd tribes opposing the Quraish tribes, as if they forgot that the time had changed, as many Persians entered Mecca when they accepted Islam, and that the classical Arabic was in Mecca during the second century, the century of collecting and codifying the language, which was infected by the impurities of Persians and loyalist who were too numerous. For this reason, the linguists went to the tribes of Najd who still maintained the purity of their language. It was very common that the Arabs who had explained to their age, were known Upper layer of Hawazin, lower layer of Tamim, Assad, Kanana and Huzail. Abu Nasr al-Farabi explains why they were limited to those tribes in the collection of language, saying: "Those tribes who transferred the language followed by Arabs, are Qais, Tamim and Assad, these are the ones who transferred the most of Arabic language, then it was taken from Huzail and some of Kanana and some of Tayians, and was not taken from any other tribe. (16)

\section{STANDARD ARABIC WAS THE LANGUAGE OF QURAISH}

It is known that the classical Arabic was known everywhere in the north, and it was a clear indication to their quick response to the Qur'an and its call, they understood it once they heard it, if we know that the Qur'an was revealed in the language of Quraish it must be the literary language that prevailed. However, it was echoed by linguists that the Holy Qur'an was revealed in seven languages, including five languages of Hawazin. It was to some people an interpretation of the Prophet's Hadith: "The Qur'an is revealed on seven characters so read it by which one is the easiest". They interpreted the characters by the languages or dialects, and when they searched about them found that there were many dialects of the Arabs, so they chose seven of them that were the most eloquent that were left to the linguists to collect their correct language material. Some believe that the Hadith does not mean any kind of the specification, but it is intended to allow the Arab tribes to read it by the different dialects that were closed to Quraish.

Some believe in the interpretation of this Hadith that the Qur'an was revealed in seven particular dialects were the most eloquent of the Arab dialects, was the one reason that misled the orientalists, as they thought that the Qur'an was revealed in the languages of the tribes of Najd, it was not revealed in the language of Quraish, but they did not notice that the same tribes that were fixed by the linguists were the closest tribes to Quraish. This is the reason that al-Tabari made it clear that Quraish language itself used to absorb the seven characters mentioned in the Prophet's Hadith.

It was not reasonable to the Prophet to leave the language of his people (Quraish) and choose the languages of other peoples. It is mentioned in the Qur'an also: "We did not send any messenger, but with the tongue of his people". The Qur'an testifies that it is revealed in the language of Quraish. As long as the orientalists concede that it came down in classical Arabic, then this standard Arabic is the same as the Quraish language. 
The reason that misguided the orientalists may be that they found the linguists going to the tribes in Najd to collect their language material, not to Quraish, as if they had forgotten that the time had changed that many non-Arabs had entered Mecca and many of them had accepted Islam and that the classical Arabic in Mecca in the second century was the century of collecting and codifying the language, which was infected by the tongue of non-Arabs and the loyalists who were very numerous. For this reason the linguists went to the tribes in Najd who were still maintaining the purity of their language. It was common that the Arabs were the most prominent of their time, namely, Hawazin, Tamim, Asad, Kanana and Huzail. Abu Nașr alFō $\bar{\alpha}$ bi explained the reason that they were limited to those tribes in collecting the language. He said: Those who were quoted by the Arab linguists and used their dialects, and chose the Arabic tongue among the all Arab tribes were Qais, Tamim and Assad... Then Huzail, Kanana and Taiyans. The linguists in the second century, when they went to the Najd tribes to collect their material from them, were looking for the springs that were still pure.

Imam al-Tabari believes that these seven dialects are the components of the Quraish dialect. He means that the Quraish dialect is a universal dialect of these seven characters, so you can read which one is the easiest. (17)

\section{DIFFERENCE BETWEEN YEMENI TONGUE AND ADNANIAN DIALECT}

Abu Amr b. al-'Ala said: "The tongue of Himyar, which is prevailed to the end of Yemen is not our tongue, and their Arabic culture is not our Arabic culture". This saying indicates that there was a difference between the tone of Himyar in the south and the dialect of Adnians in the north. The difference between the south and north was before the collapse of the Mōrib Dam. The dispersion of the Qahtānians and Hamyarians and their migration to all parts of the island and their mixing with their Adnanian brethren after their settlement, as Azad tribe: (Jurhum, Aus and Khazraj) settled in the north, but after these migrations and the stability of Yemenis and their amalgamation of Adnanians through marriage, neighborliness, governance, residence, cohabitation, and friction, after all this the language came closer, but the existence of these dialects was very small. It is not fancy that every tribe had its own language that contradicted the languages of the other tribes. As we cannot think that there were various nations in $\mathrm{Al}$-Jazeera, not tribes that were united in one nation.

The classical Arabic was prevalent in the pre-Islamic era for religious, economic, and political reasons. Poets were composing their poems in classical Arabic, leaving their local dialects, while the language of Himyar was not the language of poetry, as we see in the words of Abu Amr b. 'Ala: "The tongue of Himyar, which was prevailed to the end of Yemen was not our tongue, and their Arabic culture also was not our Arabic culture". Classical Arabic began to penetrate the doors of this language in the ignorance period itself, so we can say that the Arabization of southerners began since early times.

The words spoken by Abu Amr b. Ala means that their Arabic culture, including the language was influenced by the culture of Abyssinians and language of Persians, so it was free of Arab originality. Therefore, when the scholars came to narrate the language, they discovered that the tribes differed in eloquence. They excluded the language of Himyar, because it was almost a language alone was contrary to the language of Mudar, and because they mixed with the Abyssinians, Jews and Persians.

Some orientalists ignored this historical background that the northern tribes began to attack on the south since the middle of the fourth century AD, after the Himyar state became weak, and these tribes settled, and spread its language in the south of the island, and a large number of Arabs in south migrated to the north and adopted the language of northerners. We know 
from the inscriptions found in the Arabian Peninsula that the Arabic calligraphy originated from the Nabatean writing and the developed in northern Hijāz, and that the language was written in these inscriptions was Arabic language in its different stages. (18)

In this sense, we reject the conclusion of some orientalists say: "We have no reason to assume that there was a literary language anywhere until the Qur'an was revealed". (19) It was not reasonable for the Qur'an to be revealed in a language to people who did not know it. It is not surprising that God reveals the Qur'an to the prophet in the language of his people. There are some opinions of Orientalists in this dialect mentioned as the following:

* Theodor Nöldeke said: There were few differences between the dialects in the core parts of the Arabian Peninsula, such as Hijāz, Najd and region of Euphrates, this dialect (the fluent standard Arabic) developed by all of these dialects.

* Javidi said: It is not a certain tone to a particular tribe, but it is a mix of the dialects of the people in Najd and their neighbors.

* Fisher said: It was a certain tone, but he did not attribute it to any tribe.

* Nalino said: It was the language of those tribes were famous in the composing of poetry. The linguists and grammarians had collected their linguistic materials and examples from the people of those tribes. Those are tribes of Ma'd who were united by the kings of Kinda under the banner of a single provision before the middle of the fifth century AD. In his view it was generated from one of the civilized dialects in Najd in the time of the Kingdom of Kindah and became a literary language prevailed among the Arabs. (20)

* Brockelmann claimed that the classical Arabic was a technical language, standing above the dialects, though it was fueled by all. (21)

* Shawqī Daif has mentioned in his book: "The Pre-Islamic Era" four old Arabic dialects, three of them were written with the Southern script, these three are al-Thamudī, alLihyānī and al-Ṣafawī dialects. The fourth one is Nabatean, which is written in bold Aramaic script. He described: How did the classical Arabic grow? How did it evolve and become a literary language flourished? How then it became united under the leadership of Quraish? (22)

Quraish had a great influence because of its religious spiritual and material economical central position. It was based on guarding the Ka'ba. Its convoys were roaming all over the Arabian Peninsula. All of the tribes were meeting in the seasons of religious festivals, commercial markets and literary functions in this central place. Therefore, Quraish was as a landing place for the travelers and authorized to be focused by their eyes and hearts. So Quraish was working to refine its dialect and belongings, choosing what was the suitable word for the tongue and light in hearing from the dialects of all these tribes, Thus it was able by its fluent tone to prevail the other dialects as the whole and to be the standard classical language, in which the Qur'an was revealed.. (23)

Arabic Language grew up and passed through the various stages of development until its characteristics were completed and it flourished in Arab societies and markets. Arabs practiced its arts that flourished and grew up, and they memorized its poetry, its prose and its great wisdom. When it rose up and reached its every amount, stood on the threshold of the language of the Qur'an in its linguistic miracle, bow in front of its miraculous method liking and praising, and the scholars and scientists of Arabic tongue recognized the high quality style of its graphic statement, understanding its secrets and no wonder, because it was a sign of its greatness. On the other side, the Qur'an stood up taking its position before the people of this language challenging them in various forms, but their statement and their tongue could not resist against this challenge, even their pens were crashed in front of this challenge. 


\section{CONCLUSION}

The process of collecting the Arabic language, as it is well known, began in the blogging era after the melody began to erupt in a society where non-Arabs became a majority. Whatever the real and decisive motive of this process, the result was that the collection of Arabic language as it was done had helped to continue to deal with the Qur'an in a direct way to understand and interpret.

Since the reason for the melody was the mixing that took place in the cities, it was normal to ask for the "correct" language in the villages and the tribes that remained isolated and the men remained "Al-Arab" maintaining the "instinct", "Style" and "Right Pronunciation". If the scholars of the language did not rely on the Qur'an as a basis for the enumeration of the Arabic language, the definition of its forms and the extraction of its rules, it was not only because of the "religious achievement" but also because the process of collecting the language was to protect it from the outside, which required the creation of a "unseen" language, whether at the level of pronunciation, expression or meaning.

No doubt that the process of language preservation is an automatic process that keeps pace with the life of language, any language. However, the attempt to collect vocabularies to put them in the dictionaries define their patterns and extract their bases was quite another thing, an "industry" according to the ancients. In this case, it is necessary to set standards conduct an organized way or to become a codified organization.

Indeed, the narration of language became an industry and profession at the beginning of the second century of emigration, where some people appeared to enlist their material and intellectual energies for this purpose. The most prominent of those were Abu Amr b. al-'Ala $(154 \mathrm{H})$, Hammad al-Rawiya (d. $155 \mathrm{H})$ and Khalīl b. Ahmad $(170 \mathrm{H})$. It was in the forefront of the conditions for those who can narrate the language to have "the rough skin," a pure Arab that did not know the life of the city, the civilization did not "spoiled" his Arab originality. As well as, there was a strong competition in order to find the most exalted egalitarian Arab in the wilderness and isolation, the competition was even harder to obtain from the rare stranger words of language, which led sometimes to the resorting to those who had acquired the goods required, but by the money, so, they tended to lie and develop a phenomenon that had spread so much that the word became acceptable as long as it concerns the words of Bedouin in the construction of words and their meaning, those words that do not have the smell of civilization. (24)

It can be seen easily in general or specialized Arabic dictionaries where the "Arab world" prevails. Words, meanings, citations, and contradictions all convey to us the simple primordial sensory life of Arabs. The authors of dictionaries had been bounded to the "Arab world" in their consideration to the extent that every word does not refer to the origin of the Bedouin sense is an "alien word" should be neglected if it is not translated into Arabic or it should be mentioned with the quotation mark to indicate that it is as "the stranger". The dictionary named: "Tongue of Arabs" which is the largest and biggest Arabic dictionary, has contained or registered almost, eighty thousand words that can be an encyclopedia of Bedouin life, the life of the Bedouin Arabs in particular. It can be only a surprise when it will be noted that the current Arabic language does not transmit to us, through the ancient dictionaries, the names of tools and types of relations known to the society of Medina and Mecca under the Prophet and the four caliphs, and known to the community of Damascus then Baghdad and Cairo Etc..., As they were urban societies that used countless machines and tools, while the Bedouin language material was accumulated, with so many synonyms, to the extent that the Arabic language 
lexicon had a huge surplus of words for the meaning, but only for the Bedouin world not the urban world.

The result is that the classical Arabic, which is the language of lexicons, poetry and literature, has been and continues to convey to its people an increasingly distant world from their world, a Bedouin world living in their minds, but in their imagination and consciousness, which is completely different to the civilized world. Do we exaggerate if we succeed in saying that the Bedouin is actually the creator of the Arab world, the world that the Arabs lived on the word, the phrase, the perception and the imagination, but on the level of reason and conscience, and this world is deficient, poor, shallow and dry... just like the world that was copied by Arabic language in the "pre-Islamic era"... the era of "Pre-Arab History".

\section{Reference:}

Al-Rafi'ī. Mușțafa Șadiq. (1940). History of Arab Etiquette. Beirut, Lebanon: Arab Book House. Part 1. pp. 213-218

Muhammad Riḍā Marwa (Dr.): Tramps in the pre-Islamic era, House of the scientific books, Beirut, Lebanon, in 1990, p. 7

Studies by Orientalists in the truth of pre-Islamic poetry, translated by Dr. 'Abdul Raḥmān Badawī, Dār Al- 'Ilm, Beirut, Lebanon, the first edition, 1979, and the second edition, 1986, p. 118

Ibn Jinnī: Al-Khașā'iș, Part: 1 p. 392, see also Aḥmad 'Amīn: Dawn of Islam, Part: 2, Egyptian Revival, $8^{\text {th }}$ edition, 1974 , p. 244

Shawqiī Ḍaif (Dr.): The Pre-Islamic Era, Dār al-Ma'ārif, Egypt, p. 131

Al-Ṣāḥibī: Knowledge of the language, Pro Edition al-Mu’ayid, p. 23

Ibn Khaldun: The introduction, see Chapter: thirty two/sixth section of the book.

Al-Așfahōnī. 'Abu Al-Faraj. Songs, A narration reported by Ḥammād the narrator

'Ahmad Kamāl (Dr.): See the article entitled: "In the pre-Islamic poetry" (a look or theory), published in the issue of February, 1966, in al-Hilāl magazine, as well as see the "artistic phenomena in the pre-Islamic poetry", by Dr. Sa'd Zalam, p. 142

Orientalists curricula in Arab and Islamic Studies, released on the occasion of the celebration of the fifteenth century AH of the Arab Organization for the Education, Science and Culture, part:1, p. 428

Shawqiī Ḍaif (Dr.): Pre-Islamic Era, p. 168

Dusuqi. ‘Omar. (1954). Al-Nōbigha al-Zubȳ̄ni. Egypt: Arab Statement Committee. Third Edition. p. 31

Zalam. Sa'd. (1992). Technical phenomena in pre-Islamic poetry. Cairo: Dōr Al Manōr for printing, publishing and distribution. Second Edition. p. 143

Al-Ṣ̄hhibī. Jurisprudence of the language. First Edition. P. 23, and Ḍaif. Shawqī. Pre-Islamic Era. p. 132

Al-Așfahōnī. 'Abu Al-Faraj. (Without a date). Songs. (Sōsi). Part 2. p. 112

Ḍaif. Shawqī. (1960). Pre - Islamic Era. Cairo: Dōr Al-Ma'arif. p. 136

Ibid. p. 135

Badawī. Abd-ul-rahman. Studies of Orientalist. P. 120

Ibid. P. 120

'Ali. Jawād. (No date). The Islamic culture and contemporary life. "Dialects of the Arabs in pre Islamic Era". Cairo: Library of the renaissance.

Carl Brockelmann: History of Arabic Literature. Egypt: Dār al-Ma'ārif. Part 1, p. 42

Daif. Shawqī. (No date) The Pre-Islamic Era. Egypt: Dār al-Ma‘ārif. P. 131

Zalam. Sa'd. (1992). Technical phenomena in pre-Islamic poetry. Cairo: Dōr Al-Manōr. p. 125

See the details in the book of Muhammad Abduh. (1976). Narration and citation of language. Cairo: World of the books. 